\title{
Root-inhabiting fungi in alien plant species in relation to invasion status and soil chemical properties
}

\author{
Marta L. Majewska ${ }^{1} \cdot$ Janusz Blaszkowski $^{2} \cdot$ Marcin Nobis $^{1} \cdot$ Kaja Rola $^{1} \cdot$ \\ Agnieszka Nobis $^{1} \cdot$ Daria Lakomiec $^{1} \cdot$ Pawel Czachura $^{1} \cdot$ Szymon Zubek $^{1}$
}

Received: 26 December 2014 / Accepted: 24 April 2015 /Published online: 15 May 2015

(C) The Author(s) 2015. This article is published with open access at Springerlink.com

\begin{abstract}
In order to recognize interactions between alien vascular plants and soil microorganisms and thus better understand the mechanisms of plant invasions, we examined the mycorrhizal status, arbuscular mycorrhizal fungi (AMF) colonization rate, arbuscular mycorrhiza (AM) morphology and presence of fungal root endophytes in 37 non-native species in Central Europe. We also studied the AMF diversity and chemical properties of soils from under these species. The plant and soil materials were collected in southern Poland. We found that 35 of the species formed AM and their mycorrhizal status depended on species identity. Thirty-three taxa had AM of Arum-type alone. Lycopersicon esculentum showed intermediate AM morphology and Eragrostis albensis developed both Arum and Paris. The mycelia of dark septate endophytes (DSE) were observed in 32 of the species, while sporangia of Olpidium spp. were found in the roots of 10 . Thirteen common and worldwide occurring AMF species as well as three unidentified spore morphotypes were isolated from trap cultures established with the soils from under the plant species. Claroideoglomus claroideum, Funneliformis mosseae and Septoglomus constrictum were found the most frequently. The presence of root-inhabiting fungi and the intensity of their
\end{abstract}

Electronic supplementary material The online version of this article (doi:10.1007/s13199-015-0324-4) contains supplementary material, which is available to authorized users.

Szymon Zubek

szymon.zubek@uj.edu.pl

1 Institute of Botany, Jagiellonian University, Kopernika 27, 31-501 Kraków, Poland

2 Department of Ecology, Protection and Shaping of Environment, West Pomeranian University of Technology, Słowackiego 17, 71-434 Szczecin, Poland colonization were not correlated with soil chemical properties, plant invasion status, their local abundance and habitat type. No relationships were also found between the presence of AMF, DSE and Olpidium spp. These suggest that other edaphic conditions, plant and fungal species identity or the abundance of these fungi in soils might have an impact on the occurrence and intensity of fungal root colonization in the plants under study.

Keywords Arbuscular mycorrhizal fungi (AMF) - AMF species diversity $\cdot$ Arum-type $\cdot$ Dark septate endophytes (DSE) $\cdot$ Invasive plant species $\cdot$ Olpidium

\section{Introduction}

Alien plant invasions can be a serious danger to native ecosystems and human health and their elimination may well give rise to financial losses (Pimentel 2002). Recent studies have demonstrated that the performance of non-native plants might be influenced by their mutualistic interactions with arbuscular mycorrhizal fungi (AMF) (Richardson et al. 2000; Shah et al. 2009a). For example, it has been found that mycorrhizal fungi improve phosphorus uptake and, as a consequence, the competitiveness of two plants invasive to grassland in North America, namely Centaurea maculosa and Centaurea diffusa (Zabinski et al. 2002). Experiments conducted by Lee et al. (2014) have shown that the symbiosis of invasive Microstegium vimineum with AMF may enhance its growth and phosphorus content. The authors also pointed out that AMF improved the competitive ability of $M$. vimineum in new areas through stimulating plant tillering. Fumanal et al. (2006) found that the growth of European invader Ambrosia artemisiifolia was enhanced by AMF. In some cases, however, symbiosis with AMF may also decrease plant performance as a result of the high carbon cost and, as a consequence, it reduces the 
competitive capabilities of plants under certain conditions (Walling and Zabiński 2006; Shah et al. 2009a).

Non-native plants can, in turn, affect AMF species composition as well as the number of their propagules in soils (Shah et al. 2009a). Liang et al. (2004) observed positive role of Solidago canadensis invasion on AMF in China. They found that the number of fungal species increased in the areas it had colonized. A survey conducted by Mummey and Rilling (2006) showed the opposite findings, with a decrease in AMF diversity and a reduction in extraradical hyphal lengths being found as a result of the invasion of mycorrhizal species Centaurea maculosa. As well as directly affecting local AMF communities, the invasive plants can also influence physical and chemical soil properties. Changes in soil structure, $\mathrm{pH}$ or element content may significantly affect fungal species composition and propagule abundance. In certain habitats, all of these factors can have an impact on the competitiveness of invasive and native plant species alike (Allisopp and Holmes 2001; Blank and Young 2002; Shah et al. 2009a).

Several studies on alien plant species and AMF have been recently conducted. However, for this group of plants, investigations into the presence and potential role of other frequently occurring root-inhabiting fungi, namely dark septate endophytes (DSE) and Olpidium spp., remain neglected. Dark septate endophytes are numbered among the ascomycetous fungi which colonize plant roots intra- and intercellularly (Jumpponen 2001). Host responses to DSE generally range from mutualism to parasitism, depending on plant and fungal genotype and environmental conditions (Mandyam et al. 2012). However, some DSE strains have been found both to increase phosphorus and nitrogen concentrations in shoots and to increase plant mass, as well as enhancing seedling performance (Newsham 2011; Zijlstra et al. 2005). Olpidium spp., traditionally placed in Chytridiomycota, are weak parasites which are generally harmless to plants; however, some of them may transmit viruses which can cause serious plant diseases (Verchot-Lubicz 2003; Webster and Weber 2007). In all, these facts firmly indicate that both groups of fungal endophytes may influence the performance and competitive abilities of alien plant species.

The first step towards recognizing interactions between plants of alien origin and root-inhabiting fungi and thus better understand their invasion mechanisms is determining their presence in these plant species. Shah et al. (2009a) highlight the importance of developing exhaustive checklists of the mycorrhizal status of non-native plants from various habitat types in different biogeographical regions. To our knowledge, only two such checklists have been published to date. Shah et al. (2009b) examined the presence of AMF in the roots of alien plants in Asia, while similar research was carried out in Europe by Štajerová et al. (2009). In the latter research, 44 species of alien origin were studied, but the authors did not investigate the arbuscular mycorrhiza (AM) colonization rates and morphology, presence of fungal root endophytes and AMF species related to these plants. However, it has been shown that AM morphological type (Yamato 2004; Smith et al. 2004; Shah et al. 2009b), the intensity of AMF colonization (Treseder 2013), AMF species identity (Smith and Read 2008) and DSE (Jumpponen 2001; Massenssini et al. 2014) may influence plant performance and, as a consequence, alien plant invasions. There was also a lack of data on the relationship between soil chemical properties and the presence and abundance of root-inhabiting fungi in alien plants in the sites they inhabit. The aims of our study were thus to determine the mycorrhizal status, AMF colonization rate, AM morphology and the presence of fungal root endophytes in 37 species of alien origin in Central Europe. We have chosen species from 32 genera and 17 families that were of different life forms and invasive status. We also studied chemical properties of soils and the AMF diversity in the soils collected from under those species. Our hypothesis was that the mycorrhizal status of the investigated plants would depend on species identity. However, in view of the importance of mycorrhizae in plant nutrition, we expected that the intensity of mycorrhizal colonization would relate to soil chemical properties being highest at sites featuring low nutrients. Furthermore, as for our study the alien plants were usually collected from semi-natural and anthropogenic habitats characterized by soil disturbance, we thus also predicted that AMF species found would be common and widely distributed both in Poland and around the world.

\section{Materials and methods}

\subsection{Sample collection}

We investigated 37 vascular plant species of alien origin in Central Europe from 32 genera and 17 families that were of different life forms (cryptophyte, hemicryptophyte, phanerophyte, therophyte) and invasion status ( 1 - weed, 2 - not harmful, 3 - transformer) (Table 1). The material was collected from different habitat types (natural, semi-natural, anthropogenic; see the online resource Table S1 for details) of the randomly chosen locations in southern Poland between August and October in 2012 and 2013. The abundance of specimens of particular plant species at each site was assigned to one of the categories: 1 - small population (1-9 plants per locality), 2 - medium-size population (10-100 plants per locality, occurring in small groups or scattered), 3 - large population ( $>100$ plants per locality, forming numerous and dense patches) (Table S1). The plants were in the flowering period. They were excavated in their entirety and manually cleaned of soil. The roots were separated from the shoots and then placed in plastic containers filled with $50 \%$ ethanol in water. Soils from root zones of the plants were collected for the 


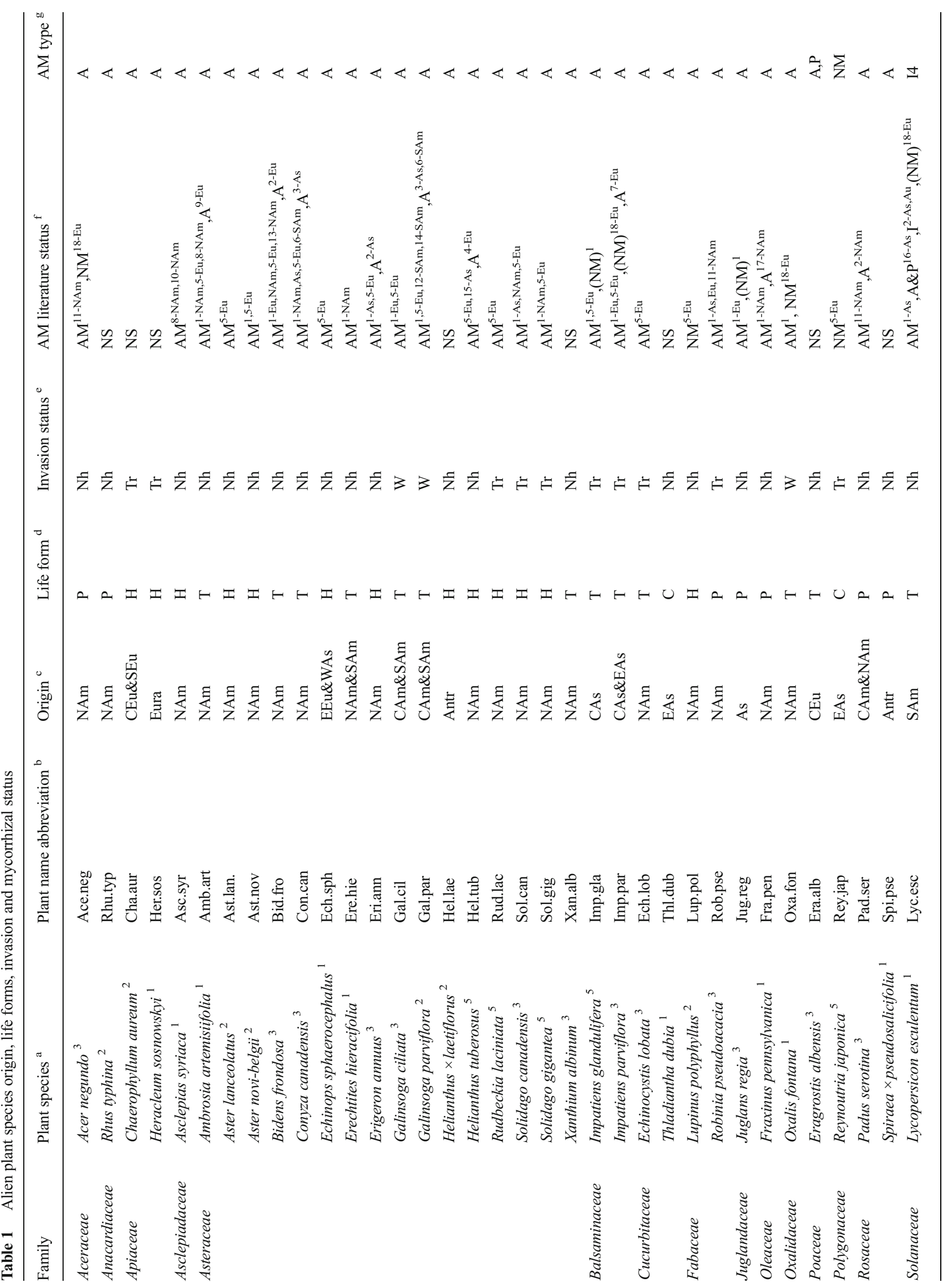


establishment of AMF trap cultures and chemical analyses. At each location, three root-system and soil subsamples were gathered and then joined to form one composite (repetition) sample. In total, 90 root and 90 soil samples were collected. For each plant species, the number of samples ranged from 1 to 5 (Table 1). The information on the sampling locations is given in Table S1. The nomenclature of plant species follow Mirek et al. (2002), with the exception of Eragrostis albensis, which is given after Scholz (1996).

\subsection{Root staining and the assessment of fungal colonization}

The roots were stained in line with Phillips and Hayman (1970) method, with modifications. The roots, which were transported to the laboratory in $50 \%$ ethanol, were washed in tap water to remove the remnants of soil. After washing, they were softened and cleared using $10 \% \mathrm{KOH}$ for $24 \mathrm{~h}$, then rinsed in several changes of water and acidified in $5 \%$ lactic acid in water for $24 \mathrm{~h}$. The roots were then stained, using $0.05 \%$ aniline blue in $80 \%$ lactic acid, for $48 \mathrm{~h}$. The final stage of the procedure was to store all the samples in $80 \%$ lactic acid for ca. 30 days before they were analyzed. The entire process was performed at a temperature of around $22{ }^{\circ} \mathrm{C}$. For each sample, between 10 and 30 stained root fragments approximately $1 \mathrm{~cm}$ long were randomly chosen, mounted on slides in glycerol:lactic acid (1:1) and pressed using cover slides. In the case of 12 species, we only managed to collect one root sample from a single stand. Each of those samples consisted of the root systems of three plants (subsamples). In these instances, we therefore studied every subsample separately (Table 1).

The AMF colonization in the roots, AM morphology and presence of fungal root endophytes were assessed at magnifications of $10 \times$ and $40 \times$, using a Nikon Eclipse 80i microscope with Nomarski interference contrast. We identified AMF colonization and AM morphology on the basis of aseptate hyphae growing (1) intracellularly, forming arbuscules terminally in the cortical cells (the Arum-type AM morphology); (2) intracellularly with arbuscules developed on coils in the cortical cells (the Paris-type) or (3) forming intermediate types (Dickson 2004). The degree of mycorrhizal colonization was determined following the calculation of mycorrhizal frequency $\left(\mathrm{F}_{\mathrm{AMF}} \%\right)$, relative mycorrhizal root length $(\mathrm{M} \%)$ and relative arbuscular richness (A\%) in accordance with the method proposed by Trouvelot et al. (1986). An estimate of $\mathrm{F}_{\mathrm{AMF}} \%$ is given as the ratio between root fragments colonized by AMF mycelium and the total number of root fragments analyzed. Parameter $\mathrm{M} \%$ is an estimate of the proportion of the root cortex that is mycorrhizal relative to the whole root system analyzed. Arbuscule abundance (A\%) is an estimate of arbuscule richness in the whole root system analyzed (Trouvelot et al. 1986). We also assessed the frequency of vesicle occurrence $\left(\mathrm{F}_{\mathrm{VES}} \%\right)$. The fine endophyte AM-type 
colonization, usually considered as Glomus tenue, was counted separately from the coarse AM-type colonization. Glomus tenue was identified on the basis of the following characteristics: approximately $1 \mu \mathrm{m}$ in diameter hyphae stained a deep blue, the presence of small vesicles or swellings and fanshaped branches (Thippayargus et al. 1999; Dodd et al. 2000).

The presence of fungal root endophytes such as dark septate endophytes (DSE) and Olpidium spp. was also observed during the assessment of AMF colonization. Dark septate endophytes colonization was identified on the basis of regularly septate hyphae, usually dark pigmented, with facultatively occurring sclerotia (Jumpponen 2001). In the case of DSE colonization, the frequency of mycelia occurrence in the roots $\left(\mathrm{F}_{\mathrm{DSE}} \%\right)$ was estimated as detailed above for AMF (Zubek and Błaszkowski 2009). In addition, the frequency of occurrence for resting sporangia of fungi from the genus Olpidium $\left(\mathrm{F}_{\mathrm{Olp}} \%\right.$ ) was assessed (Zubek and Błaszkowski 2009).

\subsection{Establishment of AMF trap cultures}

Soil samples collected from under the alien plant species being studied were used to establish trap cultures. Each trap culture was established as follows: $100 \mathrm{~g}$ of air-dried soil was placed in a $500 \mathrm{ml}$ plastic pot which was $9 \mathrm{~cm}$ wide and $12.5 \mathrm{~cm}$ high. The pot contained autoclaved, commercially available, coarse-grained sand. In total, 90 trap cultures were established. Plantago lanceolata was used as the host plant. All the cultures were kept under plant cultivation room conditions at a temperature of $22{ }^{\circ} \mathrm{C} \pm 2{ }^{\circ} \mathrm{C}$. The following light regime was employed: $270-280 \mu \mathrm{mol}$ PAR photons $\times \mathrm{m}^{-2} \times$ $\mathrm{s}^{-1}, 12 / 12 \mathrm{~h}$. The cultures were watered once a week using $35 \mathrm{ml}$ of distilled water.

\subsection{AMF spores isolation and identification}

Six months after the trap cultures were established, AMF fungal spores were isolated using the wet sieving and decanting technique (Gerdemann and Nicolson 1963). The morphological properties and subcellular structures of the spores were characterized in material mounted on a slide in a drop of polyvinyl alcohol/lactic acid/glycerol (PVLG) and a mixture of PVLG/Melzer's reagent $(4: 1, v / v)$ in line with the method proposed by Omar et al. (1979). The identification of AMF spores was carried out using an Olympus BX51 light microscope. The fungal species were identified following Błaszkowski (2012). The slides with isolated spores were deposited in the slide collection of the Department of Ecology, Protection and Shaping of Environment at the West Pomeranian University of Technology in Szczecin. Fungal species names follow Schüßler and Walker (2010), with the exception of Paraglomus majewskii and Septoglomus constrictum, which follow Błaszkowski et al. (2012) and Redecker et al. (2013), respectively.

\subsection{Chemical analyses of soils}

The soils were analyzed for $\mathrm{pH}$, measured potentiometrically in $\mathrm{H}_{2} \mathrm{O}$, using the Kjeldahl method for total nitrogen and the Tiurin method for organic carbon (Mocek and Drzymała 2010). The plant-available phosphorus $\left(\mathrm{P}_{2} \mathrm{O}_{5}\right)$ and potassium $\left(\mathrm{K}_{2} \mathrm{O}\right)$ were determined following Egner et al. (1960). Exchangeable cations $\left(\mathrm{K}^{+}, \mathrm{Na}^{+}, \mathrm{Ca}^{2+}, \mathrm{Mg}^{2+}\right)$ were measured with a flame photometer and spectrophotometer in ammonium acetate (Mocek and Drzymała 2010).

\subsection{Statistical analysis}

After Levene's test to assess the equality of variances, a oneway analysis of variance (ANOVA) followed by Tukey's HSD test was used to reveal significant differences in AMF colonization parameters as well as soil chemical properties across all plant species collected from at least two stands. In the case of DSE and Olpidium spp. colonization parameters, which turned out to be variables without a normal distribution, nonparametric Kruskal-Wallis test was applied, then the differences between particular plant species were assessed with nonparametric multiple comparison tests. The 12 species collected only from one stand were excluded from these analyses.

In order to demonstrate the diversity of AMF species associated with particular plant species cluster analysis was applied. As the matrix included the presence/absence data of fungal species, Jaccard similarity coefficient was used. The dendrogram was prepared using an unweighted pair-group average (UPGMA) clustering algorithm.

In the case of plant species collected from at least 3 stands, the within-species relationships between root colonization by AMF, DSE and Olpidium spp. $\left(\mathrm{F}_{\mathrm{AMF}} \%, \mathrm{M} \%, \mathrm{~A} \%, \mathrm{~F}_{\mathrm{VES}} \%\right.$, $\mathrm{F}_{\mathrm{DSE}} \%$ and $\mathrm{F}_{\mathrm{Olp}} \%$ ) and soil chemical properties were tested with Spearman's rank correlation coefficients. For all the plant species and soil samples under study, general (inter-species) correlation was calculated using Pearson correlation coefficients. Subsequently, the relationships between AMF, DSE and Olpidium spp. colonization parameters for all species were analyzed by the same test.

In order to verify the potential impact of the local abundance of plant species in the stand, habitat type, and invasion status of the species on the parameters of mycorrhizal colonization one-way ANOVA was applied. Within these variables, the categories were distinguished as showed in Section 2.1. The species collected only from one stand were excluded from these analyses.

Principal component analysis (PCA) was used to demonstrate the differences in AMF and endophyte colonization parameters between particular plant species in the view of their 
varied characteristics. Prior to the analysis, Pearson correlation coefficients were calculated in order to check if any strong correlations exist among colonization parameter variables that could potentially affect the results; since strong correlation was found between $M$ and A parameters $(R>0.90)$, the latter one was excluded from the analysis. AMF species richness was included in the analysis as a covariate. We used data attribute plots (graphic forms) under PCA function to show the differentiation of life form and invasion status across all examined plant species.

The statistical calculations were performed using STAT ISTICA 10, CANOCO 4.5 (ter Braak and Šmilauer 2002) and MVSP 3.1 (Kovach 1999).

\section{Results}

\subsection{AM status and morphology}

Arbuscular mycorrhiza (AM) was found in 35 out of the 37 alien plant species under study; it was not observed in Reynoutria japonica and Typha laxmannii. Although the mean values of mycorrhizal colonization parameters were diverse in the case of some plant species, we found the statistically significant differences only between non-mycorrhizal species R. japonica and several mycorrhizal species (Fig. 1a-c). Vesicles were observed in 33 of the taxa (Fig. S1). The most common mycorrhizal type was the Arum-type, which occurred alone in 33 species (Fig. 2a-g). Lycopersicon esculentum showed intermediate AM morphology and Eragrostis albensis developed both the Arum and the Paris types.

Glomи tепие was observed in four species. The mean frequencies of the occurrence of its mycelia were $1.1 \%$ in Conyza canadensis, $10.6 \%$ in Padus serotina, $11.1 \%$ in Robinia pseudoacacia, and $20.3 \%$ in Spiraea ×pseudosalicifolia. The abundance of G. tenue mycelium was low; only single hyphae were observed.

\subsection{Dark septate endophyte and Olpidium colonization}

Dark septate endophytes were found in 32 plant species. Regularly septate hyphae, accompanied sporadically by sclerotia were observed. The mycelium was brownish or stained in aniline blue (Fig. 2g-i). The mean frequency of DSE occurrence $\left(\mathrm{F}_{\mathrm{DSE}}\right)$ differed between only several plant species (Fig. 1d). The abundance of DSE mycelium in roots was low; only single hyphae and sclerotia were found in the root cortex.

The sporangia of Olpidium spp. were observed in ten species. They were stained with aniline blue. The mean frequency of the occurrence of these fungi did not differ significantly between particular plant species (Fig. 1e). The abundance of sporangia was low. We found only single sporangia in the root epidermis (Fig. 2j).

\subsection{Soil chemical properties}

Detailed information on the chemical properties of soils from under the plants being examined is given in the online resource (Table S2). We found no statistically significant differences in the chemical properties of soils collected from particular plant species except for the contents of calcium between Impatiens glandulifera and Eragrostis albensis as well as sodium between I. glandulifera and Reynoutria japonica (Table S2).

\subsection{Patterns of fungal occurrence across plant species}

The first PCA axis ( $80.7 \%$ of the total variance) distinguished between plant species with high values of mycorrhizal frequency, relative mycorrhizal root length and frequency of vesicles (left part of the diagram) and the species characterized by low mycorrhizal intensity or non-mycorrhizal (right part) (Fig. 3). The second axis (11.0\% of the total variance) separated species with high frequency of dark septate endophytes (upper part of axis 2), such as Asclepias syriaca, Fraxinus pennsylvanica, Juglans regia and Parthenocissus inserta. The plants grouped in lower left part of the diagram were associated with highest number of AMF species (Fig. 3). This group comprises species belonging mainly to Asteraceae, such as Aster lanceolatus, Aster novi-belgii, Erigeron annuus, Solidago canadensis and Xanthium albinum. The PCA ordination diagram showed that the invasion status is not directly related to the intensity of AMF colonization (Fig. 3); however, ANOVA revealed significant differences $(p<0.05)$ in relative mycorrhizal root length, relative arbuscular richness and frequency of vesicles between three groups of plant invasion status $(\mathrm{F}=5.16, p=0.008 ; \mathrm{F}=$ $5.88, p=0.004 ; \mathrm{F}=4.24, p=0.018$; for $\mathrm{M}, \mathrm{A}, \mathrm{F}_{\mathrm{VES}}$, respectively). Nevertheless, usually species of the not harmful category were characterized by the highest values of these parameters. We also found that plants from the transformer category were either highly mycorrhizal (e.g., Chaerophyllum aureum, Solidago canadensis) or just the opposite, non-mycorrhizal (Reynoutria japonica) (Fig. 3). Concerning plant life forms, phanerophytes had the highest frequency of DSE. Cryptophytes that are grouped on the right side of the diagram had low intensity of mycorrhizal colonization or were nonmycorrhizal (Fig. 3), however, this was probably due to low number of species representing this life form under study. Finally, we found that AMF colonization parameters did not depend on the habitat type and local plant species abundance in the stand (ANOVA; $p>0.05$ ).

\subsection{Fungal root colonization in relation to soil chemical properties}

At the within-species and general (among-species) levels, no statistically significant correlations were found between the 


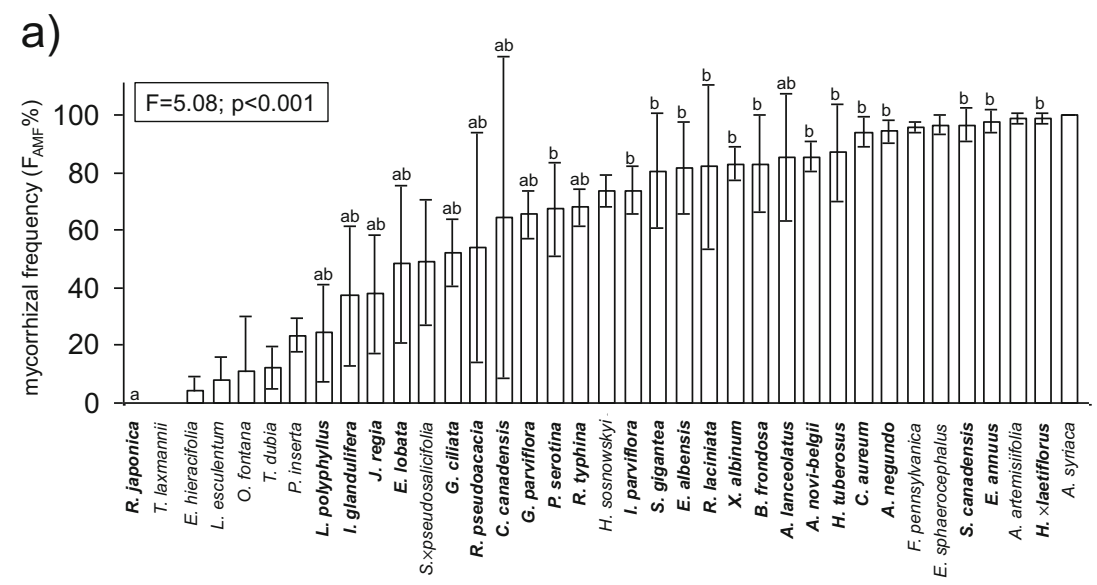

b)

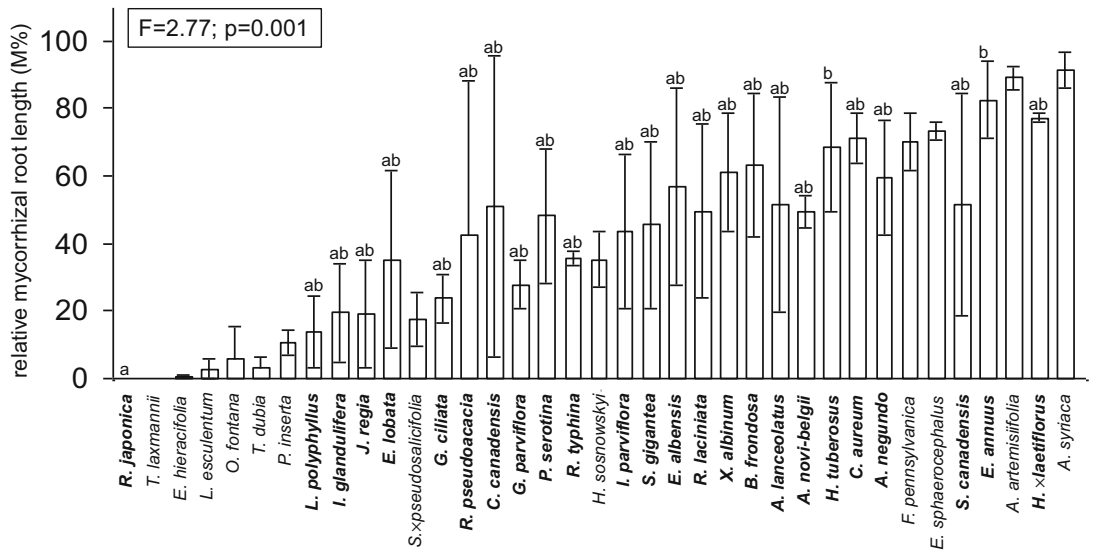

c)

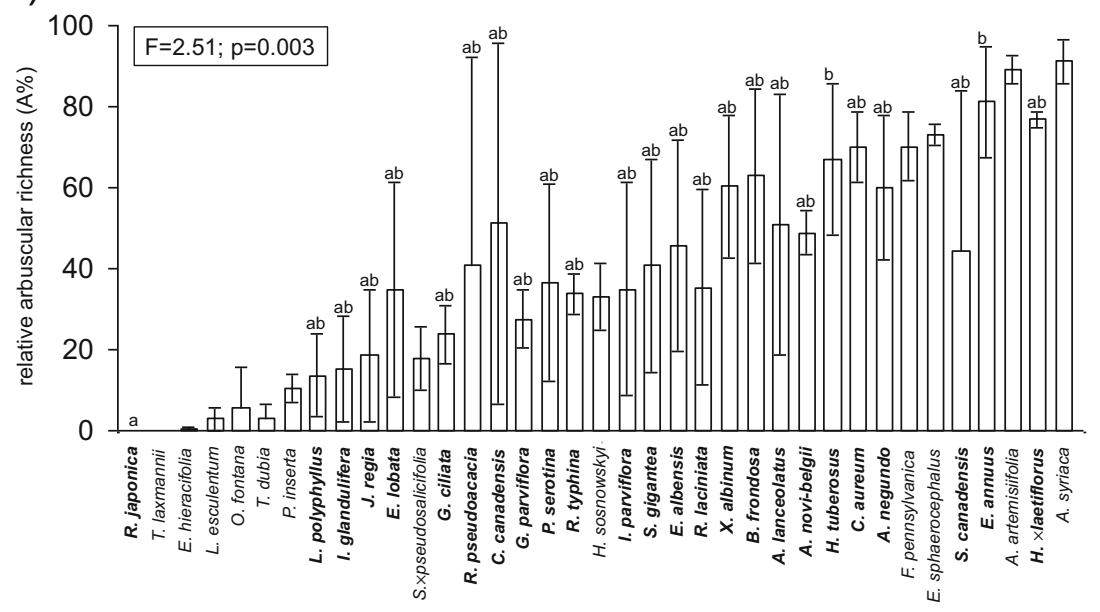

Fig. 1 The abundance of root-inhabiting fungi in plant species of alien origin in Central Europe. a-c -mycorrhizal parameters: mycorrhizal frequency $\left(\mathrm{F}_{\mathrm{AMF}}\right)$, relative mycorrhizal root length $(\mathrm{M})$ and relative arbuscular richness (A); $\mathbf{d}$ - the frequency of occurrence of dark septate endophytes $\left(\mathrm{F}_{\mathrm{DSE}}\right)$; $\mathbf{e}$ - the frequency of Olpidium occurrence $\left(\mathrm{F}_{\mathrm{Olp}}\right)$; percentages, mean \pm SD. Bold type - plant species included in the statistical analysis (see Section 2). The results of one-way ANOVA or Kruskal-Wallis test are provided. Bars not connected with the same letter indicate statistically significant differences $(p<0.05)$

correlation between the DSE/Olpidium spp. frequencies and AMF colonization parameters. 
d)

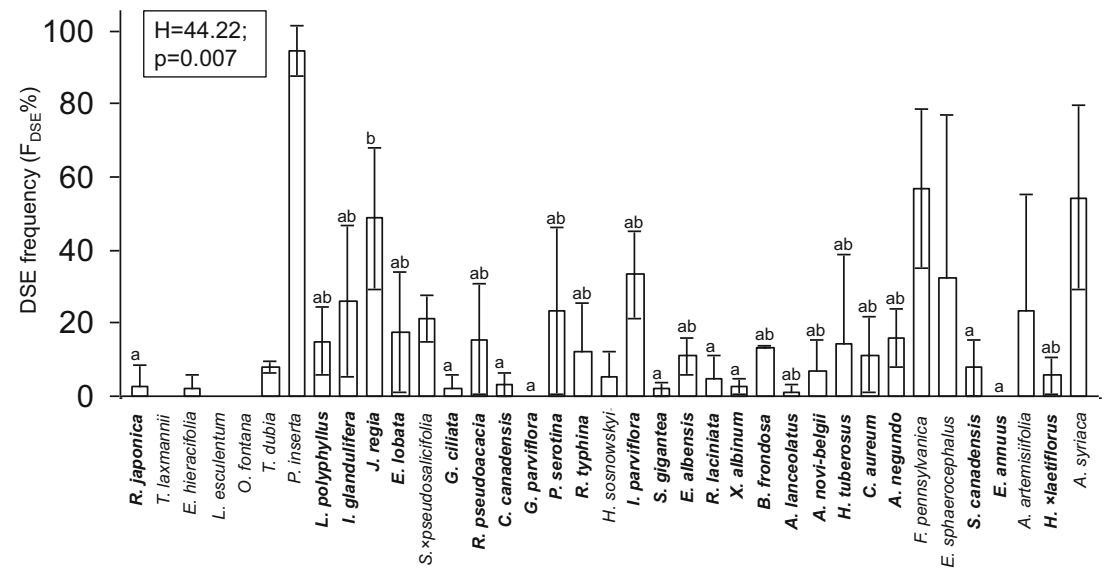

e)

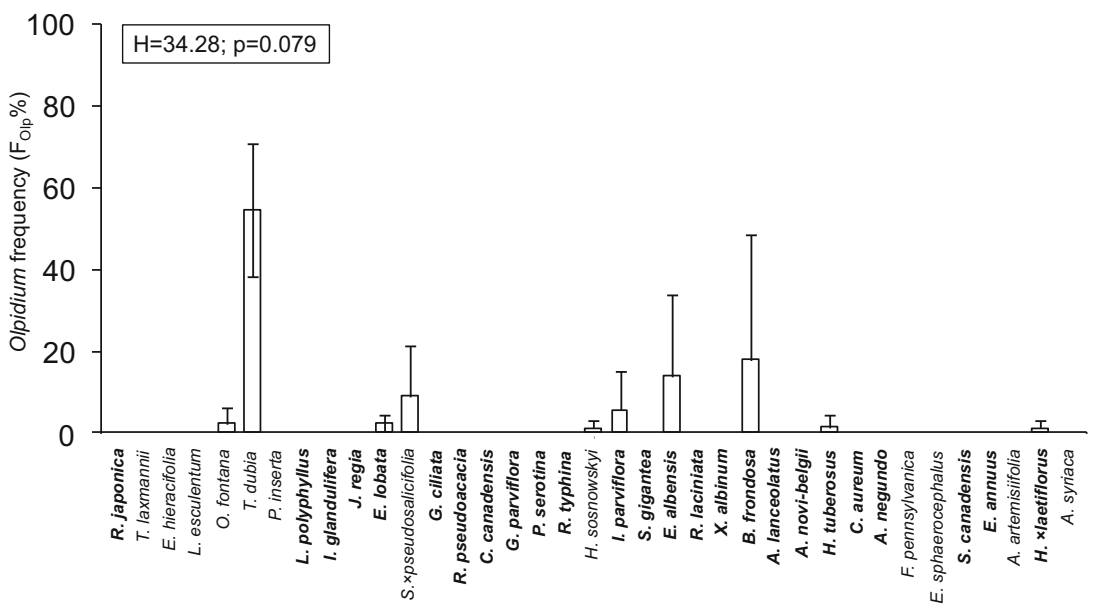

Fig. 1 (continued)

\subsection{AMF species diversity}

The spores of 13 AMF species (Glomeromycota) from five families were isolated from trap cultures established with the soils from under the plant species being examined (Figs. 4 and 5). AMF spores were found in all the trap cultures. However, owing to the low number of spores in the case of the materials from 21 cultures, it was not possible to identify fungal species. The spores of Claroideoglomus claroideum, Septoglomus costrictum and Funneliformis mosseae were the most frequently extracted, being found in 40,32 and 13 cultures, respectively. The frequency of occurrence of the other $10 \mathrm{AMF}$ species was low. They were found in 1-2 cultures. Additionally, three unidentified spore morphotypes were isolated, one of them similar to those of Diversispora, which was found in five cultures, as well as the Glomus and Funneliformis morphotypes which were found in single trap cultures. Detailed information on the presence of AMF species in particular trap cultures is presented in the online resource (Table S1).
The cluster analysis showed the association of AMF with plant species (Fig. 5). In the soils collected from under the vast majority of studied plant species either one of the following species: C. claroideum, S. constrictum, F. mosseae or various combinations of them were found. The most distinct plants were three species of American origin representing Asteraceae, i.e., Erechtites hieracifolia, Ambrosia artemisiifolia and Rudbeckia laciniata, because none of them were associated with abovementioned fungal species. Nevertheless, it is impossible to determine any pattern on the basis of AMF composition indicating a grouping of plant species representing the same family, life form or invasion status, because individual plant species are grouped completely independent of these factors (Fig. 5).

\section{Discussion}

In this article, we present a detailed report on the mycorrhizal status, AMF colonization rate, AM morphology, occurrence of 

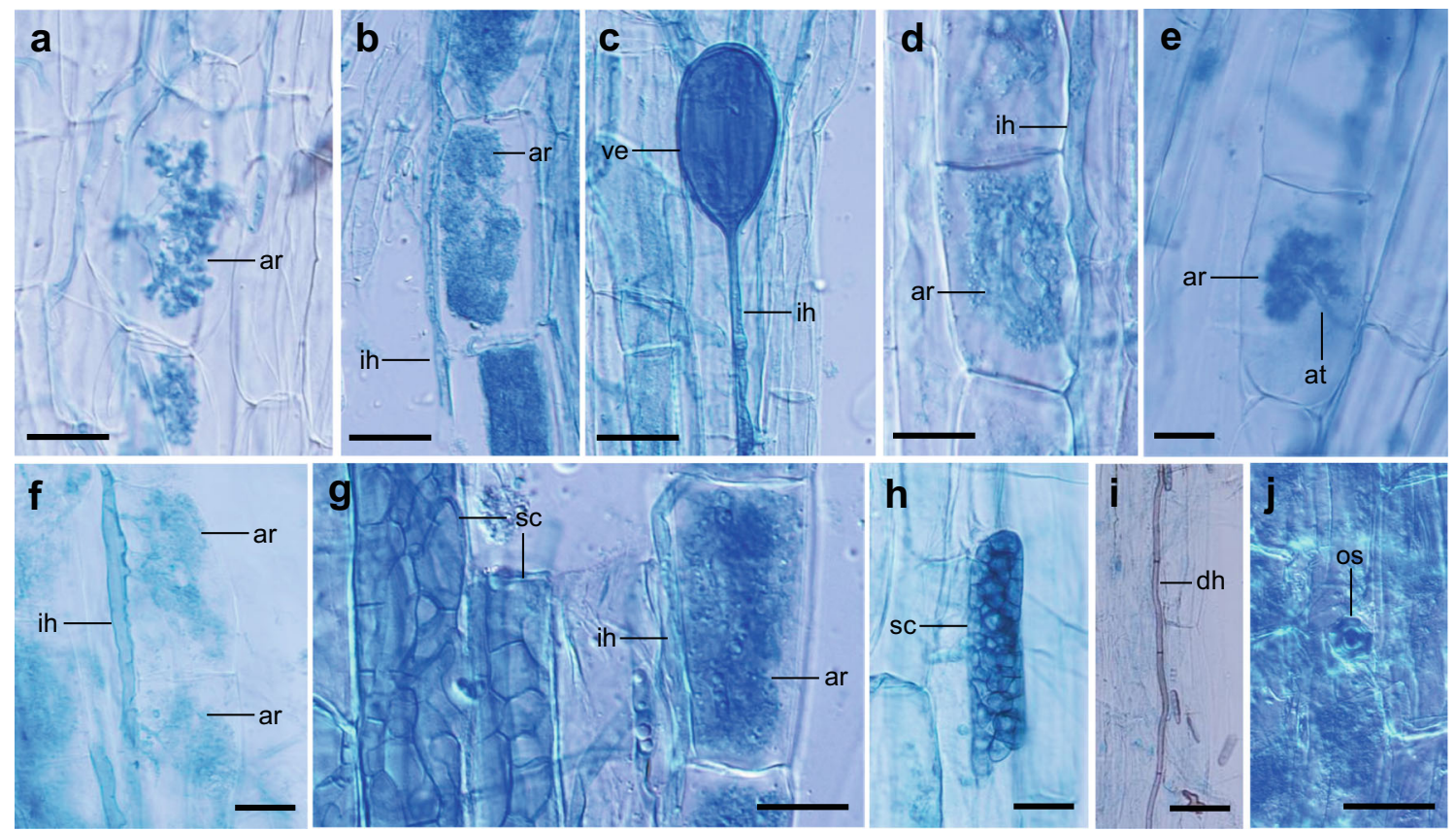

Fig. 2 Arbuscular mycorrhizal fungi (AMF), dark septate endophytes (DSE) and Olpidium sp. in the roots of plant species of alien origin in Central Europe; light micrographs of squashed roots in differential interference contrast. a-g - AMF mycelium in the cortex of Ambrosia artemisiifolia (a), Bidens frondosa $(\mathbf{b}, \mathbf{c})$, Helianthus $\times$ laetiflorus $(\mathbf{d}, \mathbf{g})$, Helianthus tuberosus (e) and Impatiens parviflora (f) (Arum-type); ar -

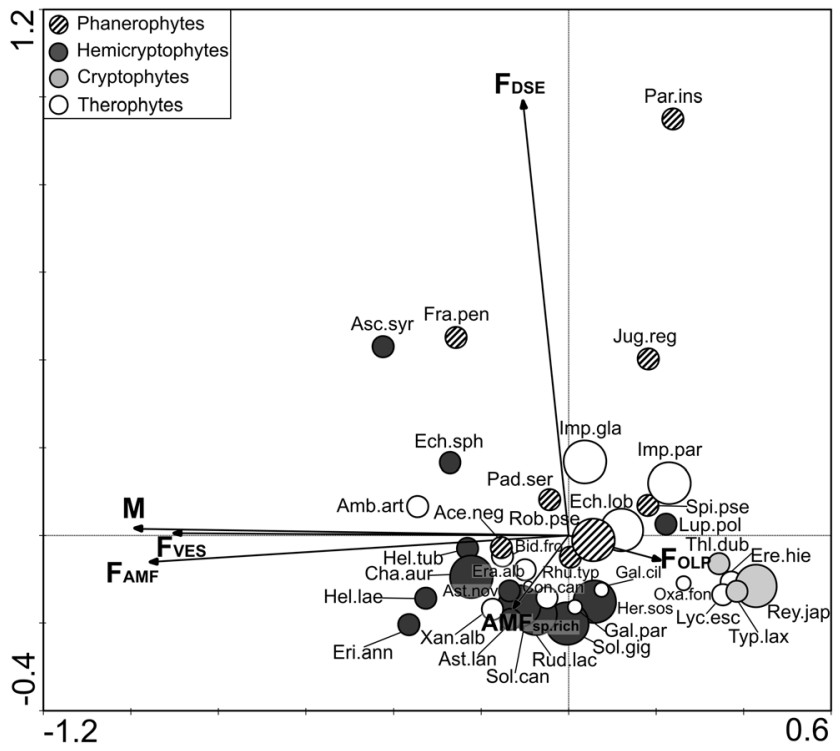

Fig. 3 Principal component analysis (PCA) ordination diagram (two first axes) of studied plant species and associated arbuscular mycorrhizal fungi (AMF), dark septate endophytes (DSE) and Olpidium spp. colonization parameters. Mycorrhizal frequency $\left(\mathrm{F}_{\mathrm{AMF}}\right)$, relative mycorrhizal root length $(\mathrm{M})$, the frequency of occurrence of AMF vesicles $\left(\mathrm{F}_{\mathrm{VES}}\right)$, the frequency of occurrence of dark septate endophytes $\left(\mathrm{F}_{\mathrm{DSE}}\right)$, the frequency of Olpidium occurrence $\left(\mathrm{F}_{\mathrm{OLP}}\right)$. AMF species richness (AMFsp.rich). The size of the circles indicates the invasion status of plant species (small weed, medium - not harmful, large - transformer). Particular colors of the circles correspond to different plant life forms. The abbreviation of species names are explained in Table 1 terminally formed arbuscules, at - arbuscule trunk, ih - hyphae growing intercelullary, ve - vesicle formed between cortical cells; $\mathbf{g}-\mathbf{i}$ - DSE hyphae (dh) and sclerotium (sc) in the outer cortex of Helianthus $\times$ laetiflorus $(\mathbf{g})$ and Impatiens parviflora $(\mathbf{h}, \mathbf{i})$ roots; $\mathbf{j}$ - Sporangium of Olpidium sp. (os) in the rhizodermal cell of Echinocystis lobata. Bars: a$\mathbf{d}, \mathbf{g}, \mathbf{j}=25 \mu \mathrm{m}, \mathbf{e}, \mathbf{f}, \mathbf{h}, \mathbf{i}=20 \mu \mathrm{m}$

fungal root endophytes and presence of AMF species in the root zones of 37 plant species of alien origin in Central Europe. Our study provides new records of the mycorrhizal status of nine species. The presence of AM in 26 plant species and the absence of mycorrhizal colonization in Reynoutria japonica were consistent with earlier observations (Table 1). In our investigations, Lupinus polyphyllus, which was previously reported by Štajerová et al. (2009) to be non-mycorrhizal, was found to form AM. The mycorrhizal status of plants under study seems to be determined by plant species identity. The species colonized by AMF are from genera and families that are considered mycorrhizal (Wang and Qiu 2006; Dickson et al. 2007). The only two non-mycorrhizal plants, $R$. japonica and Typha laxmannii, belong to families which representatives are usually non-mycorrhizal or harbor weak and facultative AMF colonization (Wang and Qiu 2006; Smith and Read 2008).

The abundance of AMF in root systems cannot be simply taken as an indicator of their effects on plants. However, in a recent meta-analysis, Treseder (2013) revealed that, when the extent of root length colonized by AMF increases, plant growth and phosphorus content often increase. The majority of plant species in our study displayed a high mycorrhizal colonization rate. This is in line with the research performed on alien plants by Shah et al. (2009b). In the field studies conducted also in southern Poland, Chmura and GucwaPrzepióra (2012) found that the mean height of Impatiens parviflora was positively correlated with mycorrhizal 
Fig. 4 Arbuscular mycorrhizal fungi (AMF) species extracted from trap cultures established from soils collected from under the alien plant species. $\mathbf{a}, \mathbf{b}$-Claroideoglomus claroideum; a-Juvenile and mature spores; $\mathbf{b}$ - Spore wall layers (swl) 1-4;

c-Funneliformis mosseae. Spore wall layers (swl) 1-3; d - Cluster with Glomus aggregatum spores; $\mathbf{e}-$ Cluster with Rhizophagus irregularis spores;

$\mathbf{f}$ - Paraglomus majewskii; g-Septoglomus constrictum. Young and mature (darkcoloured) spores; $\mathbf{h}$ - Spores (s) of Scutellospora dipurpurescens with sporogenous cell (sc). Bars: $\mathbf{a}=150 \mu \mathrm{m}, \mathbf{b}, \mathbf{c}, \mathbf{e}$, $\mathbf{g}=40 \mu \mathrm{m}, \mathbf{f}=20 \mu \mathrm{m}, \mathbf{d}, \mathbf{h}=50 \mu \mathrm{m}$
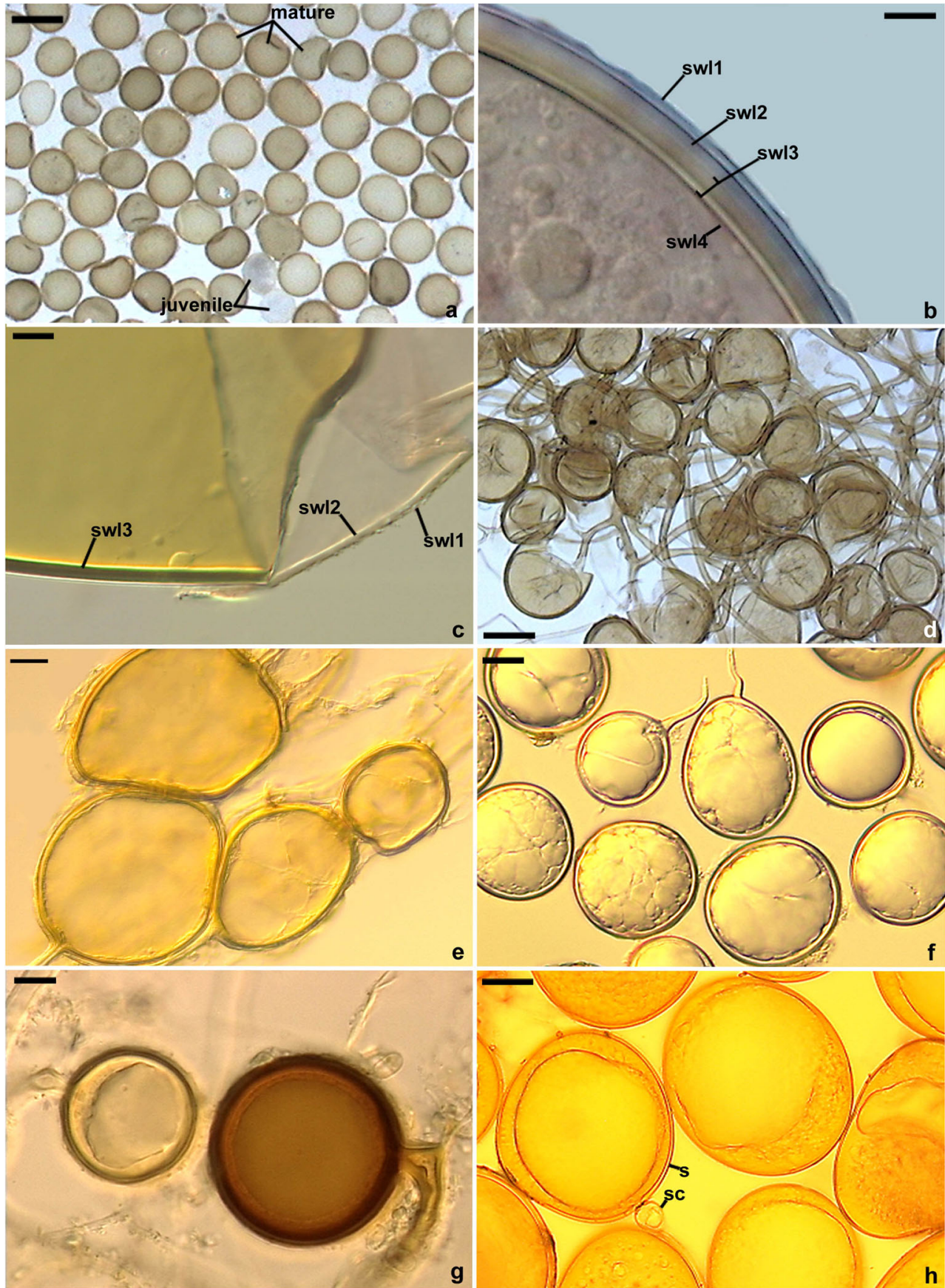

frequency $(\mathrm{F})$, relative mycorrhizal root length $(\mathrm{M})$ and relative arbuscular richness (A). The latter parameter was also positively correlated with the number of flowers and fruits of I. parviflora. The authors suggested that AMF enable the success of this species through influencing its growth and reproduction. We showed that the invasion status is not directly related to the intensity of AMF colonization and among plants from the transformer category both highly mycorrhizal and non-mycorrhizal species were found. Because the group of plants in question is very heterogeneous, it is thus unlikely that, in general, mycorrhizal association could explain the success of their invasion. However, experiments are needed to determine the impact of AMF on plant performance and thus potential role of symbiotic fungi in the invasion of some species.

In view of the importance of mycorrhizae in plant nutrition (Smith and Read 2008), we expected that the intensity of mycorrhizal colonization would relate to soil chemical properties being highest at sites featuring low nutrients. However, there were no statistically significant correlations between fungal root colonization and soil chemical properties at both inter- and within-species levels. Similar results were obtained by Nobis et al. (2015) who found no relationship between soil 


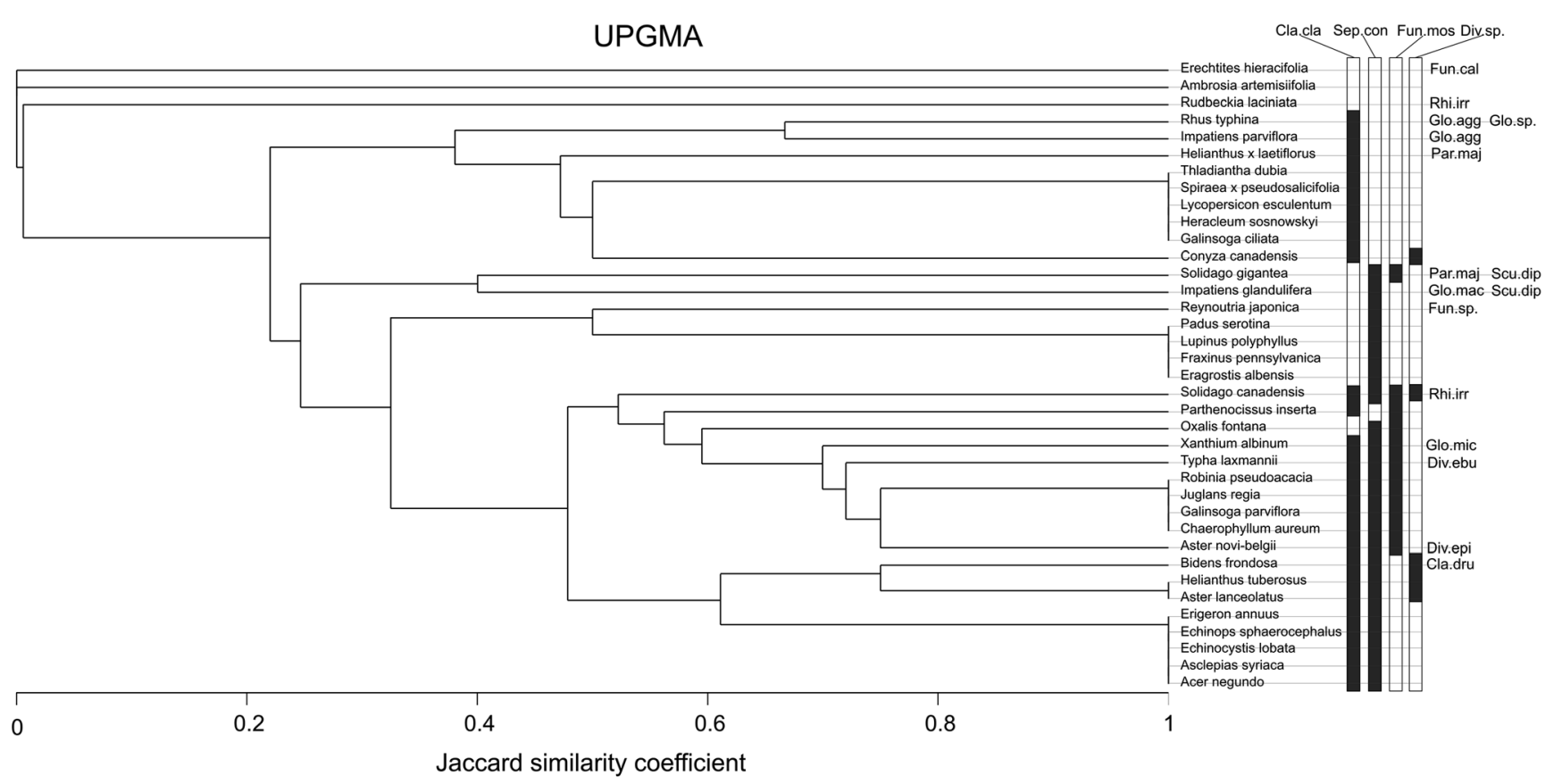

Fig. 5 Dendrogram (UPGMA, Jaccard similarity coefficient) showing the similarities between plant species on the basis of the occurrence of arbuscular mycorrhizal fungi (AMF) species extracted from trap cultures established from the soils collected from under these plants. The abbreviation of fungal species names: Cla.cla Claroideoglomus claroideum, Cla.dru Claroideoglomus drummondii, Div.ebu Diversispora eburnea, Div.epi Diversispora epigaea, Scu.dip Scutellospora

chemical properties and mycorrhizal colonization. Štajerová et al. (2009), based on the Ellenberg indicator values, showed that AMF colonization of invasive plant species decreases and the abundance of arbuscules increases with nitrogen availability in habitats. Furthermore, Chmura and Gucwa-Przepióra (2012) reported positive relationship between mycorrhizal frequency and $\mathrm{pH}$, however, the ratio of $\mathrm{C} / \mathrm{N}$ was negatively correlated with this parameter. They also found that the concentrations of total phosphorus, nitrogen and potassium had no impact on the presence of mycorrhiza. In our study, other environmental factors, such as temperature, soil moisture and structure, as well as plant and fungal species identity, the stage of plant development and its mycorrhizal dependency, may have played a role in determining AMF colonization intensity.

The most frequent AM morphotype among the alien plant species in our research was the Arum-type. A similar observation was reported by Shah et al. (2009b) for non-native plants in India. It has been pointed out that this pattern of AMF colonization may be beneficial for fast-growing plants (Yamato 2004; Shah et al. 2009b). The speed and extent of the colonization and development of arbuscules in the Arumtype are sometimes related to plant responsiveness to AMF in terms of phosphorus uptake (Smith et al. 2004). Moreover, the Paris-type AM may be more costly for plants, since the development of hyphal coils, which have higher biomass per cell than arbuscules, might require more carbon from hosts dipurpurescens, Fun.cal Funneliformis caledonium, Fun.mos Funneliformis mosseae, Fun.sp. Funneliformis sp., Glo.agg Glomus aggregatum, Glo.mac Glomus macrocarpum, Glo.mic Glomus microaggregatum, Glo.sp. Glomus sp., Par.maj Paraglomus majewskii, Rhi.irr Rhizophagus irregularis, Sep.con Septoglomus constrictum, Div.sp. morphotype with glomoid spores similar to those of Diversispora

(Dickson and Kolesik 1999; Smith et al. 2004). The dominance of the Arum-type among invasive plant species may therefore not be incidental. For 25 of the species, the AM type was determined for the first time. In the case of Ambrosia artemisiifolia, Bidens frondosa, Conyza canadensis, Erigeron annuus, Fraxinus pennsylvanica, Galinsoga parviflora, Helianthus tuberosus, Impatiens parviflora, Lycopersicon esculentum and Padus serotina, the morphotypes observed in this survey were consistent with previous reports in which individuals of these species were studied in their native or invaded areas (Brundrett et al. 1990; Kubota and Hyakumachi 2004; Fumanal et al. 2006; Dickson et al. 2007; Shah et al. 2009b; Zubek et al. 2011; Chmura and Gucwa-Przepióra 2012; Massenssini et al. 2014). Although AM morphotype may depend on fungal identity and environmental conditions, plant species identity plays a major role in determining the pattern of AMF development in roots (Cavagnaro et al. 2001; Dickson 2004; Dickson et al. 2007; Smith and Read 2008).

We found AMF spores in all 90 trap cultures and were able to identify species from 69 of them. Only a few spores were present in 21 cultures, as some AMF species may not sporulate in laboratory conditions. This is probably a result of the ecological (environmental) differences, which may be owing either to edaphic conditions or the AMF-host trap plant specificity (Zubek et al. 2013). AMF spores were found in 
the cultures established from the soils collected from the root zones of two non-host species, Reynoutria japonica and Typha laxmannii. This accords with the study conducted by Tanner and Gange (2013), where R. japonica did not eliminate AMF from beneath the invaded stands, given that the native plant species grown on soil from under this plant developed AM. The persistence of AMF under $R$. japonica and T. laxmannii could stem from accompanying mycorrhizal species, the transport of AMF propagules from adjacent areas or their long-term survival from the period before the invasion. The impact of these two plants on AMF species composition and propagule abundance requires further study.

The most common fungal species found in our research, namely Claroideoglomus claroideum, Funneliformis mosseae and Septoglomus constrictum, are widely distributed both in Poland and around the world (Błaszkowski 2012). For our study, the alien plants were usually collected from habitats characterized by soil disturbance. The dominance of these three AMF is thus comparable to that presented in previous reports, where they appeared to occur frequently in arable (Vestberg et al. 2005; Oehl et al. 2003, 2004; Zubek et al. 2012, 2013) and river valley (Nobis et al. 2015) sites in Central Europe. Although not commonly found in our study, the other AMF species also have wide distribution around the world (Błaszkowski 2012). We did not find any pattern on the basis of AMF composition indicating a grouping of plant species representing the same family, life form or invasion status, because individual plant species are grouped independent of these factors. In general, AMF associate with a wide range of hosts. However, the selectivity and functional diversity in AM symbiosis were demonstrated (Helgason et al. 2002). Although we found AMF species isolated from trap cultures established from soils collected from under single plant species, their occurrence might have been determined not by plant identity, but may be owing to their rarity in the studied area. It could also be due to the abovementioned shortcomings of trap culture method. Further molecular studies conducted on a larger number of samples are needed to show whether roots of particular alien plant species are colonized by specific AMF species.

In addition, we found three unidentified spore morphotypes in the cultures. Further morphological and molecular phylogenetic analyses are needed in order to fully characterize the fungi and place them within the Glomeromycota with certainty. In view of the permanent increase in the transportation and introduction of plants in areas well outside their natural range, the parallel arrival of AMF species cannot be excluded (Shah et al. 2009a).

Dark septate endophytes (DSE) were commonly found in the roots of the alien plants examined in our research with 32 of the 37 taxa being colonized. However, their hyphae and sclerotia occurred in low abundance. These structures cannot be regarded as specialized interfaces for the transfer of nutrients between plant and fungus and it is thus probable that DSE do not influence plant performance through direct contact with roots (Newsham 2011). Nevertheless, AndradeLinares et al. (2011) and Mandyam et al. (2012) have suggested that the effects of DSE on plants can be related to the intensity of root colonization. It is likely that the action of DSE in terms of enhanced protection from soil pathogens, the synthesis of hormones or the mineralization of organic compounds in soil is responsible for their positive impact on plants (Newsham 2011). The presence of these fungi has recently been examined by Massenssini et al. (2014) in the roots of Brazilian weeds. The authors suggested that, for the plants they surveyed, the relationship with both AMF and DSE may bring advantages in terms of increased competitiveness with crops in agricultural ecosystems. The influence of these fungi on the alien plant species we examined, their frequent occurrence in phanerophytes and their potential role in plant invasions remains to be explained. However, to our knowledge, ours is the first report on DSE presence in all the plant species we studied, with the exception of Ambrosia artemisiifolia, Asclepias syriaca, Bidens frondosa, Conyza canadensis, Galinsoga parviflora and Lycopersicon esculentum, where DSE colonization has been recently reported (Andrade-Linares et al. 2011; Stevens et al. 2010; Zhang et al. 2011; Mandyam et al. 2012; Urcelay et al. 2011).

We also provide the first report on the presence of Olpidium spp. in all the alien plant species under study with the exception of Helianthus tuberosus (Zubek et al. 2011). We observed Olpidium sporangia in the roots of ten species, including the most common invasive plants, namely Bidens frondosa, Echinocystis lobata, Helianthus tuberosus, Heracleum sosnowskyi and Impatiens parviflora. As some of the Olpidium species may transmit viruses which can cause serious plant diseases (Verchot-Lubicz 2003; Webster and Weber 2007), there is a possibility that the fungi spread with hosts during their invasions and may be a threat to native flora. However, this supposition requires confirmation.

In conclusion, the vast majority of the examined alien plant species were AMF hosts. The monocultures formed by these species probably do not have such detrimental effects on AMF abundance in soils as is usually observed for non-mycorrhizal invasive species (Lankau et al. 2014). However, the significant alterations in AMF species diversity, community structure and functional dynamics caused by mycorrhizal alien plants may occur (Liang et al. 2004; Mummey and Rilling 2006; Shah et al. 2009a). The dominance of the Arum-type among the plant species we studied is comparable with a previous report, where this $\mathrm{AM}$ morphotype was also the most common in non-native plants (Shah et al. 2009b). Further studies are needed to determine if the development of this pattern of AMF colonization may play a role in the spread of alien plants. The presence of root-inhabiting fungi and the intensity of their colonization were not correlated with soil 
chemical properties, plant invasion status, life form, their local abundance and habitat type. No relationship was also found between the occurrences of all fungal groups. These suggest that other environmental factors, plant and fungal species identities as well as the abundance of these fungi in soils, might have an impact on their occurrence and intensity of root colonization in the plants under study. The investigations on the influence of non-native plant species on the abundance and species richness of soil fungi as well as studies on the impact of AMF and fungal root endophytes on alien plant performance and competitiveness, are thus needed in order to further our understanding of the mechanisms of plant invasions.

Acknowledgments We are grateful to the editor and reviewers for their comments and suggestions of improvement. The research project was funded by the Polish National Centre of Science (DEC-2011/03/B/NZ8/00008) and the Institute of Botany at the Jagiellonian University (K/DSC/002301). It also received financial support, in part, from the Polish National Centre of Science under grant nos. 2012/05/B/NZ8/00498 and 2012/07/N/NZ8/02363.

Conflict of interest The authors declare that they have no conflict of interest.

Open Access This article is distributed under the terms of the Creative Commons Attribution 4.0 International License (http:// creativecommons.org/licenses/by/4.0/), which permits unrestricted use, distribution, and reproduction in any medium, provided you give appropriate credit to the original author(s) and the source, provide a link to the Creative Commons license, and indicate if changes were made.

\section{References}

Allisopp NP, Holmes M (2001) The impact of alien plant invasion on mycorrhizas in mountain fynbos vegetation. S Af J Bot 67:150-156

Andrade-Linares DR, Grosch R, Restrepo S, Krumbein A, Franken P (2011) Effects of dark septate endophytes on tomato plant performance. Mycorrhiza 21:413-422

Aparecido dos Santos E, Ferreira LR, Dutra Costa M, Cássia Soares da Silva M, Rodrigues dos Reis M, Cabral França A (2013) Occurrence of symbiotic fungi and rhizospheric phosphate solubilization in weeds. Acta Scientiarum. Agronomy 35:49-55

Bainard LD, Klironomos JN, Gordon AM (2011) The mycorrhizal status of 26 tree species growing in urban and rural environments. Mycorrhiza 21:91-96

Blank RR, Young JA (2002) Influence of the exotic invasive crucifer, Lepidium latifolium, on soil properties and elemental cycling. Soil Sci 167:821-829

Błaszkowski J (2012) Glomeromycota. W. Szafer Institute of Botany, Polish Academy of Sciences, Kraków

Błaszkowski J, Kovács GM, Gáspár BK, Balázs TK, Buscot F, Ryszka P (2012) The arbuscular mycorrhizal Paraglomus majewskii sp. nov. represents a distinct basal lineage in Glomeromycota. Mycologia 104:148-156
Brundrett M, Murase G, Kendrick B (1990) Comparative anatomy of roots and mycorrhizae of common Ontario trees. Can J Bot 68: $551-578$

Cavagnaro TR, Gao L-L, Smith FA, Smith SE (2001) Morphology of arbuscular mycorrhizas is influenced by fungal identity. New Phytol 151:469-475

Chmura D, Gucwa-Przepióra E (2012) Interactions between arbuscular mycorrhiza and the growth of the invasive alien annual Impatiens parviflora DC: a study of forest type and soil properties in nature reserves (S Poland). Appl Soil Ecol 62:71-80

Dickson NS (2004) The Arum-Paris continuum of mycorrhizal symbioses. New Phytol 163:187-200

Dickson S, Kolesik P (1999) Visualisation of mycorrhizal fungal structures and quantification of their surface area and volume using laser scanning confocal microscopy. Mycorrhiza 9:205-213

Dickson S, Smith A, Smith SE (2007) Structural differences in arbuscular mycorrhizal symbioses: more than 100 years after Gallaud, where next? Mycorrhiza 17:375-393

Dodd JC, Boddington CL, Rodriguez A, González-Chávez C, Mansur I (2000) Mycelium of arbuscular mycorrhizal fungi (AMF) from different genera: form, function and detection. Plant Soil 226:131-151

Egner H, Riehm H, Domingo WR (1960) Untersuchungen über die chemische Bodenanalyse als Grundlage für die Beurteilung des Nährstoffzustandes der Boden. Kungl. Lantbrukshögskolans Ann 26:199-215

Ellenberg H, Weber HE, Düll R, Wirth V, Werner W, Paulißen D (1992) Zeigerwerte von Pflanzen in Mitteleuropa, 2nd ed. Scr Geobot 18:1258

Frydman I (1957) Mykotrofizm roślinności pokrywającej gruzy i ruiny domów Wrocławia. Mycotrophic properties of plants growing on ruins in Wrocław. Acta Soc Bot Pol 26:45-60

Fumanal B, Plenchette C, Chauvel B, Bertagnolle F (2006) Which role can arbuscular mycorrhizal fungi play in the facilitation of Ambrosia artemisiifolia L. invasion in France? Mycorrhiza 17:25-35

Gerdemann JW, Nicolson TH (1963) Spores of mycorrhizal Endogone species extracted from soil by wet sieving and decanting. Trans Brit Mycol Soc 46:235-244

Helgason T, Merryweather JW, Denison J, Wilson P, Young JPW, Fitter AH (2002) Selectivity and functional diversity in arbuscular mycorrhizas of co-occurring fungi and plants from a temperate deciduous woodland. J Ecol 90:371-384

Jumpponen A (2001) Dark septate endophytes - are they mycorrhizal? Mycorrhiza 11:207-211

Kovach WL (1999) MVSP - A multivariate statistical package for Windows, ver. 3.1. Kovach Computing Services, Pentraeth, UK

Kubota M, Hyakumachi M (2004) Morphology and colonization preference of arbuscular mycorrhizal fungi in Clethra barbinervis, Cucumis sativus, and Lycopersicon esculentum. Mycoscience 45: 206-213

Lankau RA, Bauer JT, Anderson MR, Anderson RC (2014) Long-term legacies and partial recovery of mycorrhizal communities after invasive plant removal. Biol Invasions 16:1979-1990

Lee MR, Tu C, Chen X, Hu S (2014) Arbuscular mycorrhizal fungi enhance $\mathrm{P}$ uptake and alter plant morphology in the invasive plant Microstegium vimineum. Biol Invasions 16:1083-1093

Liang J, Yongjian G, Ming X, Jiakuan C, Bo L (2004) The history of Solidago canadensis invasion and the development of its mycorrhizal associations in newly-reclaimed land. Funct Pl Biol 31:979-986

Mandyam K, Fox C, Jumpponen A (2012) Septate endophyte colonization and host responses of grasses and forbs native to a tallgrass prairie. Mycorrhiza 22:109-119

Massenssini AM, Bonduki VHA, Tótola MR, Ferreira FA, Costa MD (2014) Arbuscular mycorrhizal associations and occurrence of dark septate endophytes in the roots of Brazilian weed plants. Mycorrhiza 24:153-159 
Mirek Z, Piękoś-Mirkowa H, Zając A, Zając M (eds) (2002) Flowering plants and pteridophytes of Poland. A checklist. Biodiversity of Poland. Vol. 1. W. Szafer Institute of Botany, Polish Academy of Science, Kraków

Mocek M, Drzymała S (2010) Geneza, analiza i klasyfikacja gleb. Wydawnictwo Uniwersytetu Przyrodniczego w Poznaniu, Poznań

Mummey DL, Rilling MC (2006) The invasive plant Centaurea maculosa alters arbuscular mycorrhizal fungal communities in the field. Plant Soil 288:81-90

Newsham KK (2011) A meta-analysis of plant responses to dark septate root endophytes. New Phytol 190:783-793

Nobis A, Błaszkowski J, Zubek S (2015) Arbuscular mycorrhizal fungi associations of vascular plants confined to river valleys: towards understanding the river corridor plant distribution. J Plant Res 128: $127-137$

Oehl F, Sieverding E, Ineichen K, Mäder P, Boller T, Wiemken A (2003) Impact of land use intensity on the species diversity of arbuscular mycorrhizal fungi in agroecosystems of Central Europe. Appl Environ Microbiol 69:2816-2824

Oehl F, Sieverding E, Mäder P, Dubois D, Ineichen K, Boller T, Wiemken A (2004) Impact of long-term conventional and organic farming on the diversity of arbuscular mycorrhizal fungi. Oecologia 138:574 583

Omar MB, Bolland L, Heather WA (1979) A permanent mounting medium for fungi. B Brit Mycol Soc 13:13-32

Phillips J, Hayman DS (1970) Improved procedures for clearing roots and staining parasitic and vesicular-arbuscular mycorrhizal fungi for rapid assessment of infection. T Brit Mycol Soc 55:158-161

Pimentel D (2002) Biological invasions: economic and environmental costs of alien plant, and microbe species. CRC, New York

Pyšek P, Richardson DM, Rejmánek M, Webster GL, Williamson M, Kirschner J (2004) Alien plants in checklists and floras: towards better communication between taxonomists and ecologists. Taxon 53:131-143

Redecker D, Schüßler A, Stockinger A, Stürmer SL, Morton JB, Walker C (2013) An evidence-based consensus for the classification of arbuscular mycorrhizal fungi (Glomeromycota). Mycorrhiza 23: $515-531$

Richardson DM, Allisopp N, D'Antonio CM, Milton SJ, Rejmanek M (2000) Plant invasions-the role of mutualisms. Biol Rev 75:65-93

Scholz H (1996) Eragrostis albensis (Gramineae), das Elb-Leibesgras ein neuer Neo-Endemit Mitteleuropas. Verh Bot Ver Berl Brandenburg 128:73-82

Schüßler A, Walker C (2010) The Glomeromycota: a species list with new families and new genera. In: Schüßler A, Walker C, Gloucester. Published in libraries at The Royal Botanic Garden Edinburgh, The Royal Botanic Garden Kew, Botanische Staatssammlung Munich, and Oregon State University

Sennoi R, Singkham N, Jogloy S, Boonlue S, Saksirirat W, Kesmala T, Patanothai A (2013) Biological control of southern stem rot caused by Sclerotium rolfsii using Trichoderma harzianum and arbuscular mycorrhizal fungi on Jerusalem artichoke (Helianthus tuberosus L.). Crop Prot 54:148-153

Shah MA, Reshi ZA, Khasa DP (2009a) Arbuscular mycorrhizas: drivers or passengers of alien plant invasion. Bot Rev 75:397-417

Shah MA, Reshi ZA, Khasa D (2009b) Arbusular mycorrhizal of some Kashimr Himalayan alien invasive plants. Mycorrhiza 20:67-72

Smith SE, Read DJ (2008) Mycorrhizal symbiosis, 3rd edn. Academic, London

Smith SE, Smith FA, Jakobsen I (2004) Funcional diversity in arbuscular mycorrhizal (AM) symbioses: the contribution of the mycorrhizal P uptake pathway is not correlated with mycorrhizal responses in growth or total P uptake. New Phytol 162:511-524
Štajerová K, Šmilauerová M, Šmilauer P (2009) Arbuscular mycorrhizal symbiosis of herbaceous invasive neophytes in the Czech Republic. Preslia 81:341-355

Stevens KJ, Wellner MR, Acevedo MF (2010) Dark septate endophyte and arbuscular mycorrhizal status of vegetation colonizing a bottomland hardwood forest after a 100 year flood. Aquat Bot 92:105-111

Tanner RA, Gange AC (2013) The impact of two non-native plant species on native flora performance: potential implications for habitat restoration. Plant Ecol 214:423-432

ter Braak CJF, Šmilauer P (2002) CANOCO Reference manual and CanoDraw for windows user's guide. Software for canonical community ordination, Version 4.5. Microcomputer Power, Ithaca, New York, USA

Thippayargus S, Bansal M, Abbott LK (1999) Morphology and infectivity of fine endophyte in mediterranean environment. Mycol Res 103:1369-1379

Tokarska-Guzik B, Dajdok Z, Zając M, Zając A, Urbisz A, Danielewicz W, Hołdyński C (2012) Rośliny obcego pochodzenia w Polsce ze szczególnym uwzględnieniem gatunków inwazyjnych. Generalna Dyrekcja Ochrony Środowiska, Warszawa

Treseder KK (2013) The extent of mycorrhizal colonization of roots and its influence on plant growth and phosphorus content. Plant Soil 371:1-13

Trouvelot A, Kough JL, Gianinazzi-Pearson V (1986) Mesure du taux de mycorhization VA d'un systeme radiculaire. Recherche de methodes d'estimation ayant une signification fonctionnelle. In: GianinazziPearson V, Gianinazzi S (eds) Physiological and genetical aspects of mycorrhizae. INRA Press, Paris, pp 217-221

Urcelay C, Tecco PA, Pérez M, Grilli G, Longo MS, Battistella R (2011) Mycorrhizal status and responsiveness of early successional communities from Chaquean region in central Agrentina. In Pagano M ed, Mycorrhiza: occurrence in natural and restored environments. Nova Science Publishers, New York, pp 147-163

Vannette RL, Hunter RD (2013) Mycorrhizal abundance affects the expression of plant resistance traits and herbivore performance. $\mathrm{J}$ Ecol 101:1019-1029

Verchot-Lubicz J (2003) Soilborne viruses: advances in virus movement, virus induced gene silencing, and engineered resistance. Physiol Mol Plant Pathol 62:55-63

Vestberg M, Saari K, Kukkonen S, Hurme T (2005) Mycotrophy of crops in rotation and soil amendment with peat influence the abundance and effectiveness of indigenous arbuscular mycorrhizal fungi in field soil. Mycorrhiza 15:447-458

Walling SZ, Zabiński CA (2006) Defoliation effects on arbuscular mycorrhizae and plant growth of two native bunch grasses and an invasive forb. Appl Soil Ecol 32:111-117

Wang B, Qiu YL (2006) Phylogenetic distribution and evolution of mycorrhizas in land plants. Mycorrhiza 16:299-363

Webster J, Weber RWS (2007) Introduction to fungi. Cambridge University Press, Cambridge

Yamato M (2004) Morphological types of arbuscular mycorrhizal fungi in roots of weeds on vacant land. Mycorrhiza 14:127-131

Zabinski CA, Quinn L, Callaway RM (2002) Phosphorus uptake, not carbon transfer, explains arbuscular mycorrhizal enhancement of Centaurea maculosa in the presence of native grassland species. Funct Ecol 16:758-765

Zarzycki K, Trzcińska-Tacik H, Rożański W, Szeląg Z, Wołek J, Korzeniak U (2002) Ecological indicator values of vascular plants of Poland. W. Szafer Institute of Botany, Polish Academy of Sciences, Krakow

Zhang Y, Li T, Li L, Zhao Z (2011) The colonization of plants by dark septate endophytes (DSE) in the valley-type savanna of Yunnan, southwest China. Af J Microbiol Res 5:5540-5547

Zijlstra JD, Van't Hof P, Braakhekke WG, Berendse F, Baar J, Paradi I (2005) Diversity of symbiotic root endophytes of the Helotiales in 
ericaceous plants and the grass, Deschampsia flexulosa. Stud Mycol $53: 147-162$

Zubek S, Błaszkowski J (2009) Medicinal plants as hosts of arbuscular mycorrhizal fungi and dark septate endophytes. Phytochem Rev 8: $571-580$

Zubek S, Błaszkowski J, Mleczko P (2011) Arbuscular mycorrhizal and dark septate endophyte associations of medicinal plants. Acta Soc Bot Pol 80:285-292
Zubek S, Stefanowicz AM, Błaszkowski J, Niklińska M, SeidlerŁożykowska K (2012) Arbuscular mycorrhizal fungi and soil microbial communities under contrasting fertilization of three medicinal plants. Appl Soil Ecol 59:106-115

Zubek S, Błaszkowski J, Seidler-Łożykowska K, Bąba W, Mleczko P (2013) Arbuscular mycorrhizal fungi abundance, species richness and composition under the monocultures of five medicinal plants. Acta Sci Pol-Hortoru 12:127-141 